\title{
CHANGES IN SPECIES COMPOSITION OF DESMIDS IN THE “BŁOTO” PEAT BOG (THE NIEPOŁOMICE FOREST) FROM 1954 TO 2001
}

\author{
MACIEJ WAYDA \\ Institute of Botany, Jagiellonian University \\ Lubicz 46, 31-512 Kraków, Poland \\ e-mail:wayda@fagus.ib.uj.edu.pl
}

(Received: March 28, 2003. Accepted: April 14, 2004)

\begin{abstract}
After the lapse of 48 years, a renewed study on species composition of desmids was carried out at the Błoto peat bog in the Niepołomice Forest. During this period, the peat bog underwent far-reaching changes caused by man. Out of 41 species recorded by Wasylik (1955), the occurrence of only 11 was confirmed. However, 14 species absent at the time of the earlier study were found. In all, 25 species of desmids were found. The present state of the desmid flora was brought about by increase of $\mathrm{pH}$, draining of the area, disappearance of peat mosses and probably by eutrophication of waters in the studied area.
\end{abstract}

KEY WORDS: desmids, Chlorophyta, changes in desmid flora, peat bogs, Niepołomice Forest.

\section{INTRODUCTION}

Desmids are algae which are vulnerable to changes caused by man in their natural environment. In Europe it has become almost a rule that when any study of the desmid flora is repeated in a given area after any considerable period of time, the number of found species is almost always lower than in the earlier study. This applies mainly to the western part of the continent: Great Britain (Brook 1981), Denmark (Coesel et al. 1978), and Central Europe: Germany (Scheer and Wolf-Henning 1997), and Poland (Sitkowska 1996), (Hutorowicz 2001). The Austrians have even developed a red list of the endangered species of desmids (Lenzenweger 1986). The most quoted reasons for this phenomenon is either eutrophication or oligotrophication of waters and change in their reaction.

The first studies of desmids in the Niepołomice Forest were carried out in the 19th century by. Raciborski (1885), but it is difficult to relate to these data because they lack details of the location of the sites. In the 20th century, the desmid flora of the western part on Niepołomice Forest, including the Błoto peat bog, was studied by Wasylik (1955). Since then, the ecosystem of the Niepołomice Forest has changed significantly under the influence of man. Intensive peat extraction in thas peat bog continued till the 1960s. It is likely that in that period a number of vascular plants disappeared from the area, which were recorded in earlier studies and not confirmed in later surveys (Zając
1998). The description of the effect of these alterations on changes in species composition of desmids, in the Błoto peat bog is the aim of this study.

\section{MATERIAL AND METHODS}

The Błoto peat bog is situated in the western part of the Niepołomice Forest about $20 \mathrm{~km}$ east of Kraków. It covers an area of 6 square kilometres. The nature of the patches of bog vegetation still preserved in some sites shows characteristics similar to those of mires.

Repeating the studies exactly on the sites studid by Wasylik (1955) was impossible because of major alterations in the area. Nine sites where desmids occurred most frequently were selected for permanent observations (Fig. 1). The studies were conducted in 1999-2001 during the growing seasons. In the first year collections were made at approximately four-week intervals, and later at longer intervals. During collection of the material, the following parameters of water were measured; reaction $(\mathrm{pH})$, conductivity (s) and the reduction-oxidation potential (ORP) using an electronic measuring device for water, (Hanna). The geographic co-ordinates were determined using a satellite positioning device (Trimble GPS).

The characteristics of the sites from which the material was collected are given below. The names of the vascular plant species follow the Vascular Plants of Poland, a Chec- 


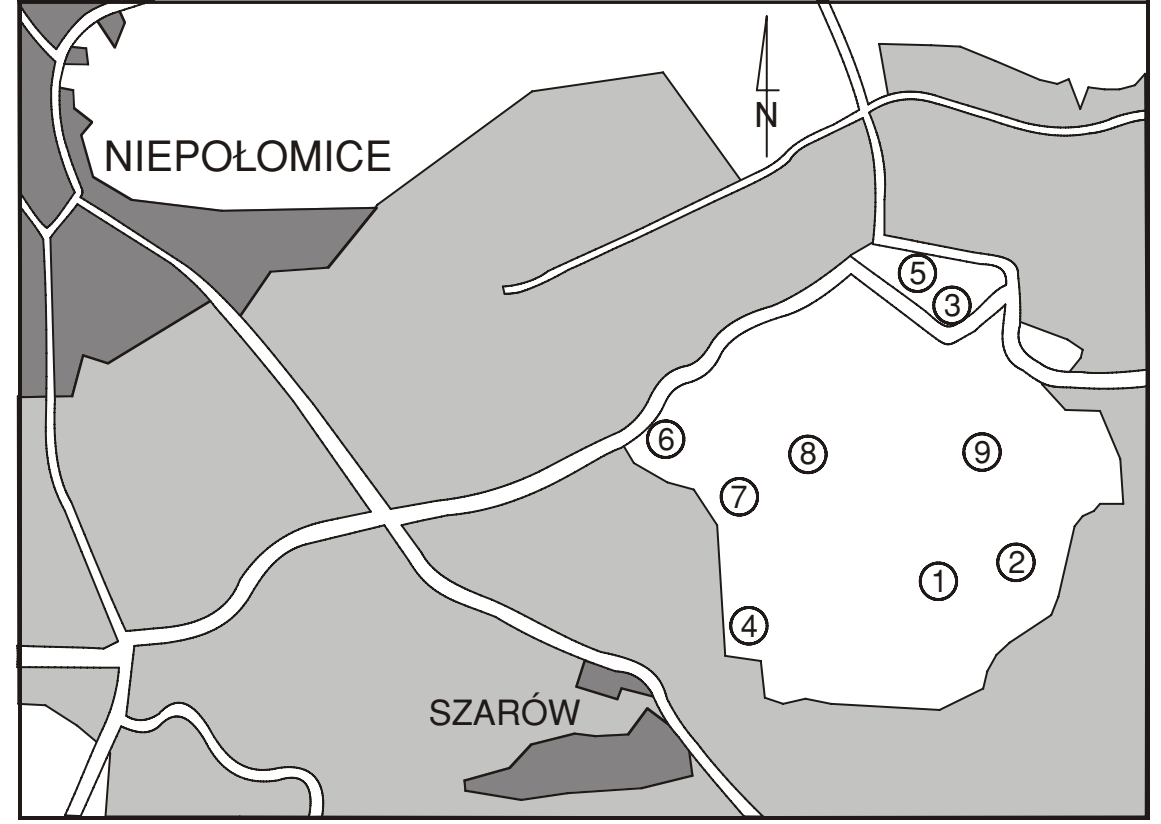

Fig. 1. Localization of the Błoto petat bog. 1, 2, ..9 - numbers of sites on which material was collected. klist (Mirek et al. 1995), and those of bryophytes - An Annoted List of Polish Mosses (Ochyra and Szmajda 1978).

1. The largest depression left by peat extraction is located near the road between Szarów and the Błoto settlement in the eastern part of the peat bog $\left(50^{\circ} 00^{\prime} 50^{\prime}\right.$ ' $\mathrm{N}$, $20^{\circ} 17^{\prime} 10^{\prime \prime}$ 'E). Water, often of a rusty colour remains there throughout the growing season. At the place of sampling its depth was up to ca. $1 \mathrm{~m}$. The following species occured near the place: Alisma plantago-aquatica, Bidens cernua, B. frondosa, Calamagrostis epigejos, Cirsium palustre, Deschampsia caespitosa, Elodea canadensis, Glyceria maxima, Juncus effusus, Mentha aquatica, Potamogeton natans, Salix cinerea, Scirpus sylvaticus, and Typha latifolia. The material was obtained by squeezing a mass-occurring liverwort Ricciocarpus natans, and by sampling with a plankton net. The physico-chemical parameters of the water were as follows: $\mathrm{pH}$ : 7.3-7.7, s: 195-310 $\mu \mathrm{s}$, ORP: 176-261 mV.

2. A draining ditch along the same road, some $0.5 \mathrm{~km}$ east of the first site $\left(50^{\circ} 00^{\prime} 52^{\prime}{ }^{\prime} \mathrm{N}, 20^{\circ} 17^{\prime} 10^{\prime}\right.$ ' $\left.\mathrm{E}\right)$. Water appears there temporarily, reaching a depth of up to $1 \mathrm{~m}$. The species occurring nearby are: Deschampsia caespitosa, Carex pseudocyperus, C. rostrata, Galium palustre, Juncus articulatus, Lemna minor, Lemna minor, Lysimachia nummularia, Mentha aquatica, and Ranunculus flammula. The material was obtained by squeezing filamentous algae of genera Spirogyra and Meugeotia, often appearing as algal blooms. The physico-chemical parameters of the water were as follows: pH: 6.7-7.1, s: 231-476 $\mu \mathrm{s}$, ORP: $-140-262 \mathrm{mV}$.

3. A draining ditch crossing the depression occupied by communities with some characteristics of peaty meadows with Molinia, some $1 \mathrm{~km}$ north-east of the Błoto settlement $\left(50^{\circ} 01^{\prime} 22^{\prime}\right.$ ' $\mathrm{N}, 20^{\circ} 16^{\prime} 55^{\prime}$ 'E). Water appears here temporarily, reaching a depth of up to $0.5 \mathrm{~m}$. The following vascular plants occurred on the site: Carex pseudocyperus, Eleocharis palustris, Juncus articulatus, J. conglomeratus, Lythrum salicaria, Molinia caerulea, Phragmites australis, Ranunculus flammula, Salix cinerea, S. rosmarinifolia, and Succisa pratensis. The material was obtained by squeezing Calliergonella cuspidata moss, and the filamentous algae of genus $\mathrm{Zy}$ - gnema. The physico-chemical parameters of the water were as follows: $\mathrm{pH}: 7.0-8.4$, s: 44-385 $\mu$ s, ORP: $-57-165 \mathrm{mV}$.

4. A draining ditch, some $0.5 \mathrm{~km}$ east of the Szarów-Sitowiec road, close to the edge of the forest on the Szarów side $\left(50^{\circ} 00^{\prime} 57^{\prime}\right.$ 'N, $20^{\circ} 15^{\prime} 51^{\prime}$ ' $\left.\mathrm{E}\right)$. The water, predominantly of rusty colour, appears here temporarily, reaching a depth of up to $0.5 \mathrm{~m}$. The following vascular plants were found on the site: Alnus glutinosa, Angelica sylvestris, Cirsium rivulare, Deschampsia caespitosa, Juncus effusus, Mentha verticillata, Phragmites australis, Ranunculus flammula, Salix cinerea, Sanguisorba officinalis, and Triglochin palustre. The material was squeezed from Calliergonella cuspidata moss. The physico-chemical parameters of the water were as follows: $\mathrm{pH}: 7.0-7.4$, s: 277-625 $\mu \mathrm{s}$, ORP: $-20-245 \mathrm{mV}$.

5. A stream, north east of a weir $\left(50^{\circ} 01^{\prime} 37^{\prime}, \mathrm{N}\right.$, $\left.20^{\circ} 16^{\prime} 57^{\prime} \mathrm{E}\right)$. The water which is of a rusty colour, flows here throughout the year. The following vascular plants were recorded on the site: Batrachium aquatile, Elodea canadensis, Glyceria maxima, Myosotis palustris, Ranunculus lingua, Rorippa amphibia, and Scirpus sylvaticus. The material was obtained by squeezing the stems of Batrachium aquatile. The physico-chemical parameters of the water were as follows: $\mathrm{pH}: 7.7-8.0$, s: $371-555 \mu \mathrm{s}$, ORP: 27-240 mV.

6. A depression left after sand extraction in a beech wood, ca. $0.5 \mathrm{~km}$ west of the Szarów-Sitowiec road, in the central part of the peat bog $\left(50^{\circ} 01^{\prime} 33^{\prime \prime} \mathrm{N}, 20^{\circ} 16^{\prime} 06^{\prime \prime} \mathrm{E}\right)$. Water appears here rarely and does not exceed the depth of $0.5 \mathrm{~m}$. The only vascular species growing in this site are: Agrostis stolonifera, Calamagrostis epigejos, Juncus articulatus, and J. conglomeratus. The material was collected by sucking sediment from the bottom. The physico-chemical parameters of the water were as follows: $\mathrm{pH}$ : 6.3-6.7, s: 54-67 $\mu \mathrm{s}$, ORP: 197-252 mV.

7. A draining ditch, ca. $1.5 \mathrm{~km}$ east of the Szarów - Sitowiec road, close to the edge of the forest (on the Szarów side) $\left(50^{\circ} 00^{\prime} 38^{\prime \prime} \mathrm{N}, 20^{\circ} 15^{\prime} 52^{\prime \prime} \mathrm{E}\right)$. The water, predominately of a rusty coulour, appears temporarily. The following vascular plants occurring in this site: Betula pubescens, Carex 
rostrata, Deschampsia caespitosa, Epilobium palustre, Galium palustre, Juncus effusus, Lemna minor, Lysimachia vulgaris, Mentha aquatica, Ranunculus flammula, and $\mathrm{Sa}$ lix aurita. The material was obtained by squeezing Fontinalis antiperytica moss. The physico-chemical parameters of the water were as follows: $\mathrm{pH}: 7.1-7.5$, s: 456-527 $\mu \mathrm{s}$, ORP: $133-277 \mathrm{mV}$.

8. A small depression left by peat extraction, ca. $1 \mathrm{~km}$ east of the Szarów - Sitowiec road $\left(50^{\circ} 01^{\prime} 10^{\prime \prime N}\right.$, $\left.20^{\circ} 16^{\prime} 11^{\prime \prime} \mathrm{E}\right)$. Water of a rusty colour persists throughout the year, reaching ca. $1 \mathrm{~m}$ in depth. The following vascular plants occurred in this site: Alisma plantago-aquatica, $\mathrm{Ca}$ rex flava, C. paniculata, C. pseudocyperus, Equisetum palustre, Juncus articulatus, J. effusus, Lycopus europaeus, Lysimachia vulgaris, Mentha aquatica, Salix aurita, and $S$. pentandra. The material was obtained by squeezing the thalli of the Chara vulgaris stonewort. The physico-chemical parameters of the water were: $\mathrm{pH}: 7.1-7.5$, s: $456-527$ us, ORP: $133-272 \mathrm{mV}$.

9. A depression left by peat extraction, ca. $1 \mathrm{~km}$ southeast of the settlement $\left(50^{\circ} 01^{\prime} 17^{\prime \prime} \mathrm{N}, 20^{\circ} 16^{\prime} 48^{\prime \prime} \mathrm{E}\right)$. Water persists here throughout the year reaching a depth of up to $1 \mathrm{~m}$ at the place of sampling. The following vascular plants occurred in this site were: Calamagrostis epigeios, Carex paniculata, C. pseudocyperus, Deschampsia caespitosa, Galium palustre, Iris pseudacorus, Juncus articulatus, J. effusus, J. inflexus, Lemna minor, L. trisulca, Lycopus europaeus, Lysimachia vulgaris, Lythrum salicaria, Phragmites australis, and Salix fragilis. The material was obtained by squeezing the stems of Lemna trisulca. The physico-chemical parameters of the water were: $\mathrm{pH}$ : $8.0-8.4$, s: 471-771 us, ORP: 23-157 mV.

After collection, the material was fixed in $4 \%$ formaldehyde. Currently, it is deposited as documentation in the herbarium of the Institute of Botany, Jagiellonian University (KRA). The photographic documentation is also kept there.

The following references were used in identifying desmid species: Bicudo (1969), Coesel (1982, 1983, 1985, 1991), Croasdale and Flint (1986, 1988), Förster (1982), Lenzenweger (1996, 1999), Lesiak (1998), Palamar-Mordvinceva (1982), Prescott et al. (1975, 1981), Ružička (1977, 1981), and Tomaszewicz (1988). Also of assistance was the iconographic collection of the Department of Algology, Institute of Botany, Polish Academy of Sciences.

\section{RESULTS}

In samples desmids occurred in small numbers and rarely constituted more than $5 \%$ of all the unicellular algae in a preparation. When the $\mathrm{pH}$ was lower than 7 and the ORP had negative values, only single specimens were found. In all samples from all sites, the diatoms of the Pennales order predominated markedly, as a rule making up more than $50 \%$ of all the unicellular algae in a preparation. In total, 25 species were successfully identified in the samples (Figs 2 and 3). The most numerous in species were the genera Cosmarium (11 species) and Closterium (9 species). The genera of Actinotaenium, Euastrum, Penium and Pleurotaenium were each represented in the flora only by a single species. These were common species frequently recorded in Poland. Except for Euastrum binale var. gutwinskii no evident forms or varieties were distinguished.

\section{LIST OF SPECIES}

The following abbreviations are used in the text: Ap width of cell apex, B - width of cell, I - width at the isthmus, $\mathrm{L}$ - length of cell, Pol-lob - width of the apical lobe.

\section{Peniaceae}

Penium exiguum W. West - L: $50 \mu \mathrm{m}, \mathrm{B}: 12.5 \mu \mathrm{m}, \mathrm{I}: 10$ $\mu \mathrm{m}, \mathrm{L} / \mathrm{B}: 4$.

\section{Closteriaceae}

Closterium acerosum (Schrank) Ehrenb. ex Ralfs - L: 500-590 $\mu \mathrm{m}$, B: 25-45 $\mu \mathrm{m}$, Ap: 5, L/B: 13.1-20. Some of the specimens displayed features similar to var. elongatum Bréb.

Cl. aciculare T. West - L: $425 \mu \mathrm{m}, \mathrm{B}: 5 \mu \mathrm{m}, \mathrm{Ap}: 2 \mu \mathrm{m}$, L/B: 85 .

Cl. archerianum Cleve in Lundell - L: 242-250 $\mu \mathrm{m}, \mathrm{B}$ : 20-30 um, Ap: 5, L/B: 8.4-12.1.

Cl. ehrenbergii Meneghini ex Ralfs - L: 290-450 um, B: 90-110 $\mu \mathrm{m}$, Ap: 5-10 $\mu \mathrm{m}, \mathrm{L} / \mathrm{B}: 3.2-4.1$. The material contained specimens showing certain features linking them to var. immamae Wolle.

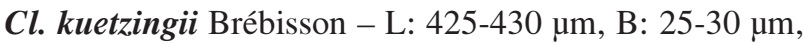
Ap: $2.5 \mu \mathrm{m}, \mathrm{L} / \mathrm{B}: 14.3-17$.

Cl. lineatum Ehrenb. ex Ralfs - L: $602 \mu \mathrm{m}, \mathrm{B}: 40 \mu \mathrm{m}$, Ap: 5 um, L/B: 15.1 .

Cl. parvulum Nägeli - L: 90-150 $\mu \mathrm{m}$, B: 15-20 $\mu \mathrm{m}$, Ap: $4 \mu \mathrm{m}, \mathrm{L} / \mathrm{B}:$ 6-7.5.

Cl. moniliferum (Bory) Ehrenb. ex Ralfs - L: 275-310 $\mu \mathrm{m}, \mathrm{B}: 40-45 \mu \mathrm{m}, \mathrm{Ap}: 5 \mu \mathrm{m}, \mathrm{L} / \mathrm{B}: 6.9$.

Cl. striolatum Ehrenb. ex Ralfs - L: 305-370 $\mu \mathrm{m}, \mathrm{B}$ : 40$50 \mu \mathrm{m}$, Ap: $7.5 \mu \mathrm{m}, \mathrm{L} / \mathrm{B}:$ 7.4-7.6.

\section{Desmidiaceae}

Pleurotaenium nodulosum (Bréb.) De Bary - L: 260 $\mu \mathrm{m}, \mathrm{B}: 30 \mu \mathrm{m}, \mathrm{I}: 25 \mu \mathrm{m}, \mathrm{L} / \mathrm{B}: 8.7$. In the course of the study, only one specimen was found.

Pl. trabecula (Ehrenb.) ex Nägeli - L: 360-410 $\mu \mathrm{m}, \mathrm{B}$ : $25 \mu \mathrm{m}, \mathrm{I}: 20 \mu \mathrm{m}, \mathrm{L} / \mathrm{B}: 16.4-18$.

Actinotaenium cruciferum (De Bary) Teiling - L: 17.5 $\mu \mathrm{m}, \mathrm{B}: 12.5 \mu \mathrm{m}, \mathrm{I}: 10 \mu \mathrm{m}, \mathrm{L} / \mathrm{B}: 1.4$.

Cosmarium abbreviatum Raciborski - L: $16 \mu \mathrm{m}, \mathrm{B}: 17$ $\mu \mathrm{m}, \mathrm{I}: 12 \mu \mathrm{m}, \mathrm{L} / \mathrm{B}: 0.9$.

Co. botrytis Meneghini ex Ralfs - L: 38-62 $\mu \mathrm{m}$, B: 30-45 $\mu \mathrm{m}, \mathrm{I}: 10-15 \mu \mathrm{m}, \mathrm{L} / \mathrm{B}: 1.3$.

Co. debaryi Archer - L: 105 um, B: 52.5 um, I: 50 um, L/B: 2.

Co. formosulum Hoff in Nordstedt - L: $45 \mu \mathrm{m}, \mathrm{B}: 30$ $\mu \mathrm{m}, \mathrm{I}: 12.5 \mu \mathrm{m}, \mathrm{L} / \mathrm{B}: 1.5$.

Co. humile (Gay) Nordstedt in De Tony - L: 15-22.5 $\mu \mathrm{m}, \mathrm{B}: 15-20 \mu \mathrm{m}, \mathrm{I}: 5 \mu \mathrm{m}, \mathrm{L} / \mathrm{B}: 1$.

Co. impressulum Elfving - L: 20-32 $\mu \mathrm{m}, \mathrm{B}: 15-25 \mu \mathrm{m}$, I: $5 \mu \mathrm{m}, \mathrm{L} / \mathrm{B}: 1.3$.

Co. obtusatum (Schmidle) Schmidle - L: 55-62.5 $\mu \mathrm{m}$, B: 50-54 $\mu \mathrm{m}, \mathrm{I}: 20 \mu \mathrm{m}, \mathrm{L} / \mathrm{B}: 1.1$.

Co. ochthodes Nordstedt - L: 75-85 $\mu \mathrm{m}, \mathrm{B}: 57-75 \mu \mathrm{m}, \mathrm{I}$ : 15-20 $\mu \mathrm{m}, \mathrm{L} / \mathrm{B}: 1.1-1.3$.

Co. pachydermum Lundell - L: $75 \mu \mathrm{m}$, B: $55 \mu \mathrm{m}, \mathrm{I}: 25$ $\mu \mathrm{m}, \mathrm{L} / \mathrm{B}: 1.4$. 


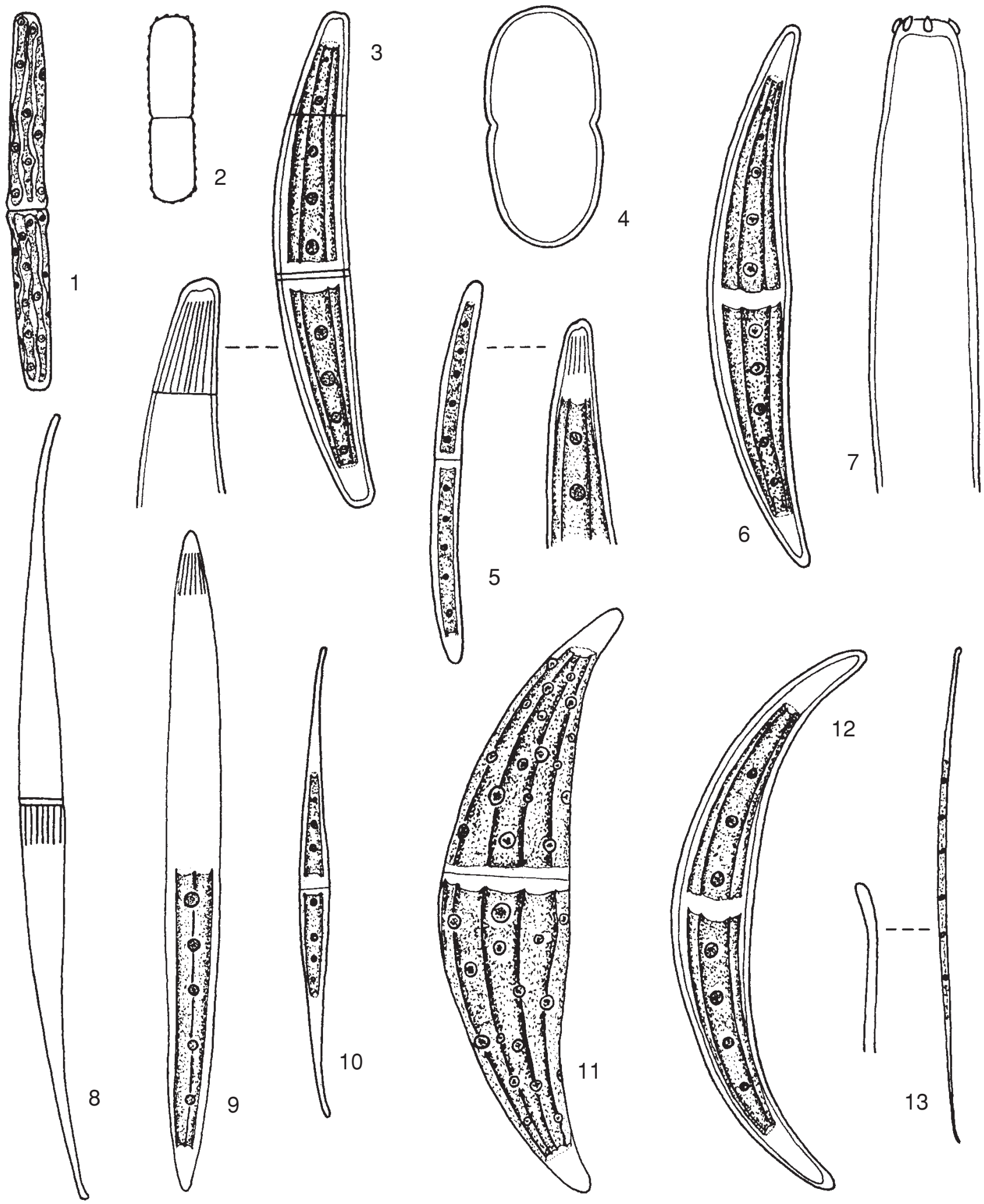

Fig. 2. Illustrations of desmids recorded from the Błoto peat bog: $1-P l$. trabecula, $2-P$. exiguum, $3-C l$. striolatum, $4-$ Ac. cruciferum, 5 - Cl. lineatum, $6-C l$. moniliferum, $7-\mathrm{Pl}$. nodulosum, $8-\mathrm{Cl}$. kuetzingii, $9-\mathrm{Cl}$. acerosum, $10-\mathrm{Cl}$. rostratum, $11-\mathrm{Cl}$. ehrenbergii, $12-\mathrm{Cl}$. parvulum, $13-\mathrm{Cl}$. aciculare.

Co. reniforme (Ralfs) Archer - L: $55 \mu \mathrm{m}, \mathrm{B}: 50 \mu \mathrm{m}, \mathrm{I}$ : 20 um, L/B: 1.1.

Co. tetraophthalmum Bréb. in Ralfs - L: 110-125 $\mu \mathrm{m}$,

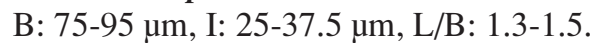

Euastrum binale (Turpin) Ehrenb. ex Ralfs var. gutwinskii (Schmidle) Homfeld - L: $19 \mu \mathrm{m}, \mathrm{B}: 20 \mu \mathrm{m}, \mathrm{I}: 5 \mu \mathrm{m}$, Pol-lob: 9 um L/B: 1.

The species composition of desmids occurring at particular sites is given in Table 1. 


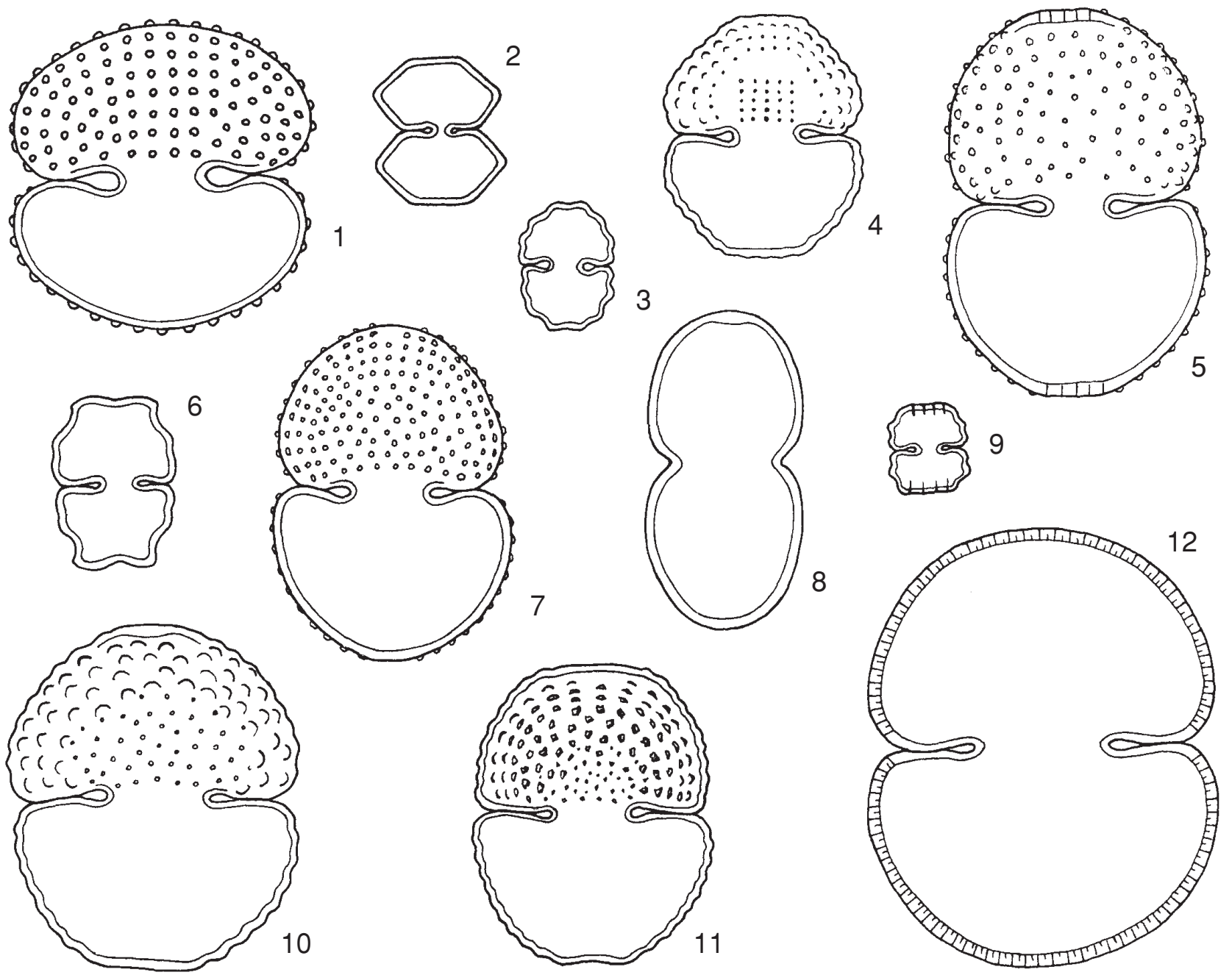

Fig. 3. Illustrations of desmids recorded from the Błoto peat bog: 1 - Co. reniforme, 2 - Co. abbreviatum, 3 - Co. impressulum, 4 - Co. formosulum, 5 - Co. tetraophthalmum, 6 - Eu. binale, 7 -Co. botrytis, 8 -Co. debaryi, 9 -Co. humile, 10 - Co. obtusatum, 11 - Co. ochthodes, 12 - Co. pachydermum.

\section{DISCUSSION}

The present flora of the Błoto peat bog is much poorer (the number of species decreased by $50 \%$ ) than it was 48 years ago. At present, such genera as Desmidium, Hyalotheca, Micrasterias, Staurastrum, Staurodesmus, and Spherozosma are not represented at all. The detailed comparison of the species listed in the recent flora and those recorded by Wasylik (1955) are given in Table 2. Out of the taxa found in 1954 only 11 taxa (ca. 25\%) have survived. These are common species, often recorded in Poland. The presence of almost three-fourths of the species was not confirmed. None of the rare species such as: Closterium decorum Brébisson, Cosmarium pseudobroomei Wolle and Staurastrum retusum Turner were recorded. Most of the species which were not confirmed in the recent studies probably disappeared because of habitat transformation.

Fourteen species which were not reported earlier from this peat bog were found. All these are common and widely distributed algal species. The noteworthy species in this group are the calciphilous species such as: Closterium acerosum, $\mathrm{Cl}$. aciculare, and Cosmarium humile.

In recent decades, the habitat conditions in the study area have undergone major alterations. These are associated with peat extraction which continued still in the 1960 s, and with draining of the area by the Iglopol Company of Debica. Compared with the conditions prevailing in the 1950s, the $\mathrm{pH}$ coefficient increased, the area was significantly drained, and possibly eutrophication of the water occurred. Perhaps these changes played a different role in the transformation of the desmid flora.

\section{Increase in $\mathrm{pH}$}

In the $1950 \mathrm{~s}$, waters in the area showed a slightly acidic reaction. The $\mathrm{pH}$ coefficient oscillated within the 6-7 range. Now the reaction is slightly alkaline and $\mathrm{pH}$ is mostly above 7. The concentration of hydrogen ions is of paramount importance to the life of the algae. This was proven experimentally by Moss (1973), and since then also repeatedly confirmed by field observations (Matuła 1995). It affects, inter alia, the availability of dissolved inorganic carbon (DIC), necessary for photosynthesis. When the reaction is acidic, almost all DIC appears in the form of easily assimilated carbon dioxide, while with $\mathrm{pH}$ exceeding 7, the concentration of bicarbonate ions increases rapidly at the expense of free carbon dioxide. At pH approaching 8.5, almost all DIC occur as bicarbonate ions. Only some algal species are capable of using bicarbonate ions as a source of 
TABLE 1. The distribution of species in the sites.

\begin{tabular}{|c|c|c|c|c|c|c|c|c|c|}
\hline Species & 1 & 2 & 3 & 4 & 5 & 6 & 7 & 8 & 9 \\
\hline Penium exiguum & - & - & - & - & - & - & - & - & + \\
\hline Closterium acerosum & - & + & + & - & + & - & - & - & - \\
\hline Cl. aciculare & - & - & - & - & - & - & - & + & - \\
\hline Cl. archerianum & + & + & - & - & - & - & - & + & - \\
\hline Cl. ehrenbergii & + & + & + & + & + & - & + & + & + \\
\hline Cl. kuetzingii & - & + & + & + & + & - & - & + & - \\
\hline Cl. lineatum & - & - & + & - & - & - & - & - & - \\
\hline Cl. moniliferum & + & + & + & + & + & - & + & + & + \\
\hline Cl. parvulum & + & + & + & + & - & - & - & + & - \\
\hline Cl. striolatum & + & - & - & - & - & - & - & - & - \\
\hline Pleurotaenium trabecula & - & + & + & - & - & - & - & + & - \\
\hline Pl. nodulosum & - & - & - & - & - & - & - & + & - \\
\hline Actinotaenium cruciferum & - & - & - & - & - & + & - & - & - \\
\hline Cosmarium abbreviatum & - & - & - & - & - & - & - & + & - \\
\hline Co. botrytis & - & + & - & - & - & - & - & + & + \\
\hline Co. debaryi & + & - & - & - & - & - & - & - & - \\
\hline Co.formosulum & - & - & - & - & - & - & + & - & + \\
\hline Co. humile & - & - & - & + & - & - & + & + & - \\
\hline Co. impressulum & + & + & - & - & - & - & - & + & + \\
\hline Co. obtusatum & + & + & - & - & - & - & - & + & + \\
\hline Co. ochthodes & - & + & - & - & - & - & - & + & + \\
\hline Co.pachydermum & + & - & - & - & - & - & - & - & - \\
\hline Co. reniforme & - & - & - & - & - & - & - & + & - \\
\hline Co. tetraophthalmum & - & - & + & - & - & - & - & + & - \\
\hline Euastrum binale & - & - & - & - & - & + & - & - & - \\
\hline
\end{tabular}

carbon for photosynthesis. This regards, inter alia, Closterium acerosum (Brook 1981), a species which had not been found within the Błoto peat bog earlier. Most of the desmid species prefer acidic water with $\mathrm{pH}$ ranging from 4 to 7 , whereas only a few taxa live in waters of alkaline reaction (Woelkering and Gough 1976; Brook 1981; Gerath 1993). The highest species diversity occurs when reaction is closer to neutral (Matuła 1995). The shifts of reaction from acidic to alkaline are very adverse to desmids. This effect was determined by Hutorowicz (2001), who described the changes found in algae living in the plankton of the Smolak lake following the application of lime. Out of 23 desmid species living in the lake plankton, where the reaction of water was acidic, after liming (alkaline reaction) only 7 species were found. The increase of $\mathrm{pH}$ above 7 favours a massive occurrence of the Lemnaceae species, which cut off light penetrating into the body of water. At present, Lemna minor occupies the water table of most bodies of water within the Błoto peat bog. In the flora compiled by Wasylik (1955), the species which are very vulnerable to alkalisation constituted ca. $44 \%$, vulnerable - ca. $5 \%$, and invulnerable - ca. $41 \%$ (the level of vulnerability of some $10 \%$ of the species is difficult to determine). In the recent flora, the very vulnerable species constitute ca. $8 \%$, vulnerable - ca. $11 \%$, and invulnerable - ca. $81 \%$.

\section{Draining of the area}

Before the intensive peat extraction, the peat bog had many muddy pools and sphagnum puddles. At present, pools are few and even those are mostly of a temporary nature. This situation limits seriously the occurrence of planktonic desmids and of those having an unfavourable surface-to-volume ratio, and being thus very vulnerable to drying, such as species of the genus Micrasterias. Additionally, great fluctuations in the concentrations of mineral salts occur in such pools.
TABLE 2. The list of species found in 1954 and in the present study. The species occurring recently are denoted in bold characters. The species, which were found again, were additionally underlined. The column (1) shows the vulnerability of the species to alkalisation of the habitat, and (2) - its vulnerability to eutrophication.

1. The vulnerability to alkalisation: $(++)$ - acidophilous species, very vulnerable, $(+)$ - vulnerable acidophilous to neutral species, $(-)-$ species with broad spectrum or alkaliphilous species, (?) - species which preferences could not be determined.

2. The vulnerability to eutrophication: $(++)$ - oligotrophic species, very vulnerable, $(+)$ - species tolerating mesotrophic habitats, $(-)-$ species which can live in both oligotrophic and eutrophic habitats, (?) - species which preferences could not be determined. The data on preferences were obtained from references cited at the end of this paper.

\begin{tabular}{|c|c|c|}
\hline Species & 1 & 2 \\
\hline Penium exiguum & ++ & ++ \\
\hline Closterium acerosum & - & - \\
\hline Cl. aciculare & - & - \\
\hline Cl. archerianum & + & + \\
\hline Cl. attenuatum & ++ & + \\
\hline Cl. calosporum & ++ & + \\
\hline Cl. decorum & $?$ & $?$ \\
\hline Cl. ehrenbergii & - & - \\
\hline Cl. gracille & ++ & + \\
\hline Cl. kuetzingii & - & - \\
\hline Cl. leibleinii & - & - \\
\hline Cl. lineatum & + & + \\
\hline$\underline{\text { Cl. moniliferum }}$ & - & - \\
\hline Cl.parvulum & - & + \\
\hline Cl. striolatum & + & + \\
\hline Cl. venus & - & - \\
\hline Pleurotaenium trabecula & - & - \\
\hline Pl. minutum & ++ & ++ \\
\hline Pl. nodulosum & - & + \\
\hline Actinotaenium cruciferum & ++ & + \\
\hline Ac. turgidum & ++ & + \\
\hline Cosmarium abbreviatum & - & - \\
\hline Co. botrytis & - & - \\
\hline Co. connatum & ++ & + \\
\hline Co.cucumis & ++ & + \\
\hline Co. debaryi & - & + \\
\hline Co.formosulum & - & - \\
\hline Co. granatum & - & - \\
\hline Co. humile & - & - \\
\hline Co. impressulum & - & - \\
\hline Co. margaritatum & - & - \\
\hline Co. moniliforme & $?$ & $?$ \\
\hline Co. naegelianum & $?$ & $?$ \\
\hline Co. obtusatum & - & - \\
\hline Co. ochthodes & - & - \\
\hline Co. pachydermum & - & - \\
\hline Co.portianum & ++ & + \\
\hline Co.pseudobroomei & $?$ & $?$ \\
\hline Co.pseudoexiguum & ++ & + \\
\hline Co.pygmaeum & ++ & ++ \\
\hline Co. reniforme & - & - \\
\hline Co. tetraophthalmum & - & + \\
\hline Co. undulatum & - & + \\
\hline Euastrum binale & - & + \\
\hline Eu. oblongum & ++ & - \\
\hline Eu.pectinatum & ++ & + \\
\hline Micrasterias crux-melitensis & - & - \\
\hline Staurastrum inflexum & - & - \\
\hline St. punctulatum & - & - \\
\hline St. retusum & ++ & ++ \\
\hline St. teliferum & ++ & + \\
\hline Staurodesmus dejectus & ++ & + \\
\hline Desmidium schwartzii & ++ & + \\
\hline Hyalotheca dissiliens & ++ & + \\
\hline Sphaerozosma excavata & ++ & + \\
\hline
\end{tabular}




\section{Disappearance of peat mosses}

The bryophytes, previously growing abundantly in the area, have been almost totally destroyed. These plants are of paramount importance for the desmids, as they can acidify habitats reduce the concentration of calcium ions and retain water preventing the latter from drying. There are also reasons to believe that in these conditions symbiotic relationships can be established between desmids and some bacteria (Fisher and Wilcox 1996). As a rule, the samples obtained by squeezing peat mosses show high species diversity (Woelkering and Gough 1976) and many species are termed 'sphagnophilous'. The number of species avoiding peat mosses is very low. A good example is Cosmarium impressulum (Croasdale and Flint 1988), a species found in the recent study and not recorded in the area by Wasylik (1955).

\section{Eutrophication of waters}

There is no direct evidence of the Błoto peat bog undergoing eutrophication in recent decades. As a mire, it has probably been of a mesotrophic nature. At present, most of the bodies of water in the area are of eutrophic character, as indicated, inter alia, by the high levels of ionic conductivity. In the flora from 48 years ago, the species vulnerable to eutrophication consisted ca. 10\%, vulnerable ca. $46 \%$, and invulnerable - ca. 37\% (some $7 \%$ of the species cannot be classified). At present, the very vulnerable species comprise ca. $4 \%$, vulnerable ca. $35 \%$ whereas those invulnerable - ca. $61 \%$. It should be noted that both Actinotaenium cruciferum and Penium exiguum, species of oligotrophic habitats and vulnerable to eutrophication occur in low numbers. Most of the desmid species are those of mesotrophic habitats (Brook1981), (Gerath 1993) and the eutrophication of habitats results in a decrease in their diversity (Brook 1981). This process was regarded as a cause of the changes in the species composition of desmid flora in some peat bogs, e.g. the Na Rąbieniu peat bog (Sitkowska 1996). The likely mechanism of replacing the species of oligotrophic habitats by those of eutrophic habitats when a habitat undergoes eutrophication, is to eliminate the former in the competition for phosphorus (Spijkerman and Coesel 1996, 1998). Some of the species of eutrophic habitats, e.g. Closterium ehrenbergii (which did not occur at the Błoto peat bog in 1954) are capable of obtaining phosphorus by breaking down organic esters (Gerath 1993).

The Błoto peat bog is now extremely transformed. It is probable that the present species composition of desmids will persist unless the area is completely drained of water.

\section{ACKNOWLEDGEMENTS}

I would like to cordially thank Dr. Grażyna Tomaszewicz for her help in identifying the species in the material.

\section{LITERATURE CITED}

BICUDO C.E. 1969. Contribution to the Knowledge of the Desmids of the State of Sao Paulo, Brazil. Nova Hedwigia 17: 433-548.

BROOK. A.J. 1981. The Biology of Desmids. Bot. Monogr. 16: $1-276$.
COESEL P.F.M., KWAKKESTEIN R., VERSCHOOR A. 1978. Oligotrophication and eutrophication tendencies in some Dutch moorland pools as reflected in their desmid flora. Hydrobiologia: 61: 21-31.

COESEL P.F.M. 1982. De Desmidiaceeën Van Nederland-Sieralgen. Deel 1. Fam. Mesotaeniaceae, Gonatozygonaceae, Peniaceae. pp. 32. Wetenschappelifke Mededelingen van de Koninklijke Nederlandse Natuurhistorische Vereniging, Utrecht.

COESEL P.F.M. 1983. De Desmidiaceeën Van Nederland-Sieralgen. Deel 2. Fam. Closteriaceae. pp. 49. Wetenschappelifke Mededelingen van de Koninklijke Nederlandse Natuurhistorische Vereniging, Utrecht.

COESEL P.F.M. 1985. De Desmidiaceeën Van Nederland-Sieralgen. Deel 3. Fam. Desmidiaceae (1). pp. 69. Wetenschappelifke Mededelingen van de Koninklijke Nederlandse Natuurhistorische Vereniging, Utrecht.

COESEL P.F.M. 1991. De Desmidiaceeën Van Nederland-Sieralgen. Deel 4. Fam. Desmidiaceae (2). pp. 88. Wetenschappelifke Mededelingen van de Koninklijke Nederlandse Natuurhistorische Vereniging, Utrecht.

CROASDALE H., FLINT E. A. 1986. Flora of New Zealand. Freshwater algae, Chlorophyta, Desmids with ecological comments on their habitats. Vol. 1. pp. vii +133 with plates 1-27. V.R. Ward, Goverment Printer, Wellington, New Zealand.

CROASDALE H., FLINT E.A. 1988. Flora of New Zealand. Freshwater algae, Chlorophyta, Desmids with ecological comments on their habitats. Vol. 2. pp. $\mathrm{x}+147$ with plates: 28-61. V.R. Ward, Goverment Printer, Wellington, New Zealand.

FISHER M.M., WILCOX L.W. 1996. Desmid - bacterial associations in Sphagnum - dominated Wisconsin Peatlands. J. Phycol. 32: 643-549.

FÖRSTER K. 1982. Das Phytoplankton des Süsswassers, Systematic und Biologie. Conjugatophyceae, Zygnematales und Desmidiales (excl. Zygnemataceae). In: Huber-Pestalozii G. (ed.), Die Binnengewässer. 16 (8/1). viii + 542 pp. E. Schweizerbartsche, Verlangsbuchhandlung, Stuttgart.

GERATH J.F. 1993. The biology of desmids: a decade of progress. Progress in Phycological Research 9: 81-192.

HUTOROWICZ A. 2001. Phytoplankton of the humic lake Smolak against a background physico-chemical changes caused by liming and fertilization. Idee ekologiczne t. 14 (7) ser. zeszyty. pp. 130. Sorus, Olsztyn (in Polish).

LESIAK T. 1998. Desmids of the Zbyszek peat bog, Central Poland. Fragm. Flor. Geobot. 43 (1): 65-76.

LENZENWEGER R. 1986. Rote Liste gefährdeteren Zieralgen (Desmidiales) Österreichs. In: Niklfeld H. et al. (Hrsg.): Rote Liste gefährdeteren Pflanzen Österreichs. Grüne Reihe des Bundesministeriums für Gesundheit und Umweltschutz 5: 200-202.

LENZENWEGER R. 1996. Desmidiaceenflora von Österreich. Teil 1 mit 17 Tafeln und 117 Abbildungen im Text. in: Bibliotheca Phycologica: 101: pp. 162. J. Cramer, Berlin-Stuttgart.

LENZENWEGER R. 1999. Desmidiaceenflora von Österreich. teil 3 mit 22 Tafeln und zahlreichen Abbildungen im Text. in: Bibliotheca Phycologica: 104: pp. 218. J. Cramer, Berlin-Stuttgart.

MATUŁA J. 1995. Trophic Conditions of Lower Silesian PeatBog Algae. Zeszyty Naukowe Akademii Rolniczej we Wrocławiu, nr 265, Rozprawy CXXXV. Wydział Rolniczny, Wrocław, Wydawnictwo Akademii Rolniczej, pp. 132. (in Polish with English summary)

MIREK Z., PIĘKOŚ-MIRKOWA H., ZAJĄC A., ZAJĄC M. 1995. Vascular Plants of Poland. A Checklist. Pol. Bot. Stud. Guidebook ser. 15: 1-303.

MOSS B. 1973. The influence of enviromental factors on the distribution of freshwater algae. An experimental study II. The role of $\mathrm{pH}$ and the carbon dioxide-bicarbonate system. J. Ecol. 61: 157-177.

OCHYRA R., SZMAJDA P. 1978. An annotated List of Polish Mosses. Fragm. Flor. Geobot. 24 (1): 93-145. 
PALAMAR-MORDVINCEVA G.M. 1982. Zelenyje vodorosli. Klass Konjugaty. Poriadok Desmidievye [„Green algae. Class Conjugatophyceae. Order Desmidiales"]. In: Opredelitel presnovodnykh vodorosleyi SSSR ["Manual of the freshwater algae of the SSSR"]. 11 (2). pp. 620. Isdatelstvo Nauka, Leningrad (in Russian).

PRESCOTT. G.W., CROASDALE H.T., VINYARD W.C. 1975. A synopsis of North American desmids. Part II. Desmidiaceae. Placodermae. Section 1. pp. 274. University of Nebrasca Press, Lincoln.

PRESCOTT. G.W., CROASDALE H.T., VINYARD W.C., BICUDO C.E. De M. 1981. A synopsis of North American desmids. Part II. Desmidiaceae. Placodermae. Section 3. pp. 720. University of Nebrasca Press, Lincoln and London.

RACIBORSKI M. 1885. Desmidyje okolic Krakowa. Sprawozd. Kom. Fizjogr. A. U. 19: (in Polish)

RŮŽIČKKA J. 1977. Die Desmidiaceen Mitteleuropas 1 (1): vi + 292 pp. mit 1-44 Tafeln. E. Schweizebartsche Verlagsbuchhandlung, Stuttgart.

RŮŽIČKA J. 1981. Die Desmidiaceen Mitteleuropas 1 (2): ix + 293-736 pp. mit 45-117 Tafeln. E. Schweizebartsche Verlagsbuchhandlung, Stuttgart.

SCHEER T., WOLF-HENNING K. 1997. Bestandsveränderungen der Desmidiaceen im Naturschtzgebiet Barsee und Pech- see (Berlin) in den letzten siebzig Jahren unter anthropogenen Einflüssen. Nova Hedwigia 65 (1-4): 385-409.

SITKOWSKA M. 1996. Changes in the species composition of green algae in the Rąbień peat-bog near Łódź in 1982-1984. Fragm. Flor. Geobot. ser. Polonica 3: 213-220 (in Polish with English summary)

SPIJKERMAN E., COESEL P.F.M. 1996. Phosphorus uptake and growth kinetics of two planktonic desmid species. Eur. J. Phycol. 31: 53-60.

SPIJKERMAN E., COESEL P.F.M. 1998. Different response mechanisms of two planktonic desmid species (Chlorophyceae) to a single saturating addition of phosphate. J. Phycol. 34: 438-445.

TOMASZEWICZ G. 1988. Desmids of the transitional bogs of the Middle Mazowsze Lowland. Monographiae Botanicae. 70: 1-86.

WASYLIK K. 1955. Desmidiaceae des Westteiles der Puszcza Niepołomicka (Wald von Niepołomice) in Polen. Fragm. Flor. Geobot. 3 (1): 151-169 (in Polish with German summary).

WOELKERING W.J., GOUGH S.B. 1976. Wisconsin desmids III. Desmid community composition and distribution in relation to lake type and water chemistry. Hydrobiologia. 51: 3-32.

ZAJĄC M., ZAJĄC A. (eds) 1998. Distribution Atlas of Vascular Plants in Cracow Province. Legally protected, endangered, vulnerable and rare species. pp. 134. Laboratory of Computer Chorology, Institute of Botany, Jagiellonian University, Cracow. 